Jurnal Ilmu Hukum

FAKULTAS HUKUM UMSU

\title{
EKSEKUSI TERHADAP PEMBATALAN SURAT IZIN MENDIRIKAN BANGUNAN PADA PERKARA TATA USAHA NEGARA
}

\author{
Zainuddin \\ Fakultas Hukum Universitas Muhammadiyah Sumatera Utara \\ Jl. Kapt. Mukhtar Basri No. 3, Medan - Sumatera Utara \\ Email: zainuddin@umsu.ac.id
}

\begin{abstract}
Abstrak
Keputusan administrasi Negara dan Pemerintah yaitu keputusan yang dibuat oleh Badan Pemerintah, baik yang sifatnya (regreling) yang mengatur maupun yang bersifat ketetapan (beschikking). Membuat ketetapan merupakan perbuatan hukum. Sebagai perbuatan hukum ketetapan itu melahirkan hak dan atau kewajiban, dan ketetapan yang melahirkan hak dan atau kewajiban itu disebut ketepan positif. Penelitian ini dikategorikan pada penelitian yang berjenis normatif, yang mana sumber data yang digunakan adalah sumber data sekunder dengan data yang didapat melalui studi kepustakaan (library research) dengan pengolahan data analisis kualitatif. yang menjadi fokus permasalahan dalam penelitian ini adalah bagaimana eksekusi terhadap pembatalan surat izin mendirikan bangunan pada perkara tata usaha negara.
\end{abstract}

\section{Kata Kunci: Pembatalan, Izin, Mendirikan, Bangunan, Perkara}

\section{Abstract}

State and Government administrative decisions, namely decisions made by Government Agencies, both regulating and statutory (beschikking). Making provisions is a legal act. As a legal act the provision gives birth to rights and / or obligations, and the provisions that give birth to rights and / or obligations are called positive terms. This research is categorized in normative type research, where the data sources used are secondary data sources with data obtained through library research (library research) by processing qualitative data analysis. the focus of the problem in this study is how the execution of the cancellation of the building permit letter in the state administration case.

Keywoeds: Cancellation, Permettion, Establish, Building, Case

\section{PENDAHULUAN}

Badan atau Pejabat pemerintah dalam menjalankan tugas dan pekerjaannya sering membuat berbagai kebijakan. Kebijakan itu diambil, dirumuskan dan dituangkan dalam bentuk keputusan. Biasanya setelah kebijakan menjadi keputusan maka baru dirumuskan secara administratif sebagai ketetapan yang konkret, kasuistis, dan individuali dengan menggunakan freies ermessen yaitu badan atau pejabat tata usaha negara yang bersangkutan merumuskan kebijaksanaannya itu dalam berbagai bentuk 'juridische regels' seperti peraturan, pedoman, pengumuman surat edaran dan mengumumkan kebijaksanaan itu (Suady Husin. 2011, h. 24).

Keputusan administrasi negara dan pemerintah yaitu keputusan yang dibuat oleh badan pemerintah, baik yang sifatnya (regreling) yang mengatur maupun yang bersifat ketetapan (beschikking) (Suady Husin. 2011, h. 24). Membuat ketetapan merupakan perbuatan hukum. Sebagai perbuatan hukum ketetapan itu melahirkan hak dan atau kewajiban, dan ketetapan yang melahirkan hak dan atau kewajiban itu disebut ketepan positif (Suady Husin. 2011, h. 26). 
DEIEGA LATA

Jurnal Ilmu Hukum

FAKULTAS HUKUM UMSU
Eksekusi Terhadap Pembatalan...(Zainuddin)

Volume 4 Nomor 2, Juli-Desember 2019, 271-288

DOI: https://doi.org/10.30596/dll.v4i2.3198

Keputusan yang bersifat ketetapan itu mengikat seseorang tertentu saja atau beberapa orang tertentu seperti, Kartu Tanda Penduduk (KTP), Surat Izin Mengemudi (SIM), Surat Izin Mendirikan Bangunan (SIMB), Akta Perkawinan dan seterusnya.

Van der Pot (Anna Erliyana, 2005) menyebut 4 syarat yang harus dipenuhi agar keputusan dapat berlaku sah:

1. Dibuat oleh organ yang berwenang

2. Pembentukannya tidak boleh memuat kekurangan yuridis

3. Harus diberibentuk

4. Isi dan tujuan harus sesuai dengan peraturan dasarnya.

Berkaitan dengan hal di atas, sebagai contoh pada tanggal 24 Maret 2015 Walikota Medan sebagai Pejabat Tata Usaha Negara (Pejabat TUN) mengeluarkan suatu keputusan yang bersifat penetapan yaitu Keputusan Walikota Medan Nomor 645/299. K Tentang: Izin Mendirikan Bangunanan. PT. Sinar Menara Deli, yang pada isinya memberikan hak-hak kepada Sinar Menara Deli untuk mendirikan bangunan yang ada di Jalan Putri Hijau/Guru Patimpus No.1 OPQ, Kelurahan Kesawan, Kecamatan Medan Barat, Kota Medan yaitu pekerjaan pembangunan 7 (tujuh) tower bangunan campuran (Mall, Apartemen, Perkantoran, dan lain sebagainya) setinggi 200 meter diatas tanah seluas $52.306 \mathrm{~m}^{2}$.

Pemerhati yang peduli terhadap lingkungan akibat diadakannya pembangunan 7 (tujuh) tower bangunan campuran (Mall, Apartemen, Perkantoran, dan lain sebagainya) setinggi 200 meter di atas tanah seluas $52.306 \mathrm{M}^{2}$ itu adalah Yayasan Citra Keadilan yang merupakan organisasi lingkungan hidup yang sudah bergerak cukup lama dari tahun 2002 sampai sekarang dengan keberadaannya sebagai organisasi berbadan hukum. Yayasan Citra Keadilan menggugat Surat Keputusan yang diterbitkan oleh Walikota Medan tersebut mewakili kepentingan lingkungan yang akan berdampak buruk dari pembangunan Super Mall yang akan dibangun melalui SIMB yang diterbitkan Walikota Medan. Organisasi lingkungan tersebut mengajukan gugatannya ke Pengadilan Tata Usaha Negara Medan dan diputus pada tanggal 28 Oktober 2015 dengan Amar membatalkan SIMB yang diterbitkan oleh Walikota Medan tersebut.

Akibat adanya Putusan tingkat pertama tersebut, Walikota Medan dan PT. Sinar Menara Deli pun melakukan Banding terhadap putusan tingkat pertama (judex facti) itu yang pada akhirnya diputuskan oleh Pengadilan Tinggi Tata Usaha Negara Medan dengan Amar bahwa gugatan para penggugat tidak dapat diterima yang diputuskan pada tanggal 03 Maret 2016. Berlanjut dari perkara tersebut, organisasi lingkungan hidup tidak puas dengan putusan PTTUN. Maka, melanjutkan upaya hukum Kasasi ke Mahkamah Agung (MA).

Berdasarkan uraian di atas terkait Kasasi dari organisasi lingkungan hidup tersebut. Mahkamah Agung dalam amar putusannya nomor 274 K/TUN/2016 mengabulkan permohonan kasasi yang dilakukan oleh Yayasan Citra Keadilan dengan manyatakan batal Surat Keputusan Walikota Medan No. 645/299.K Tentang Izin Mendirikan Bangunan tanggal 24 Maret 2015, atas nama PT. Sinar Menara Deli dan mewajibkan kepada Walikota Medan untuk mencabut Surat Keputusan Walikota Medan No. 645/299.K Tentang Izin Mendirikan Bangunan tanggal 24 Maret 2015, an. PT. Sinar Menara Deli. 
DEIFGA IATA

Jurnal Ilmu Hukum

FAKULTAS HUKUM UMSU
Eksekusi Terhadap Pembatalan...(Zainuddin)

Volume 4 Nomor 2, Juli-Desember 2019, 271-288

DOI: https://doi.org/10.30596/dll.v4i2.3198

Setelah adanya putusan dari Mahkamah Agung tersebut pihak yang dimenangkan menyurati Pemko Medan untuk membatalkan objek gugatan namun tanggapan dari pemerintahan kota Medan melalui Kabag Hukumnya mengatakan bahwa tidak ada menerima surat dan menerima panggilan dari Pengadilan Tata Usaha Negara Medan, dan mengatakan bahwa Pemerintahan Kota Medan sudah mengajukan permohonan Peninjauan Kembali (PK) di Mahkamah Agung (MA Batalkan IMB Podomoro Deli City Medan Gini Sikap Pemko Medan, 2018). Putusan dari Mahkamah Agung dan tanggapan dari Pemerintahan Kota Medan jika dikaitkan dengan Pasal 66 ayat 2 Undang-Undang Nomor 14 Tahun 1985 tentang Mahkamah Agung bahwa permohonan peninjauan kembali tidak menangguhkan atau menghentikan pelaksanaan putusan pengadilan.

Berdasarkan uraian di atas jelas bahwa apa yang dilakukan pemerintahan kota medan sudah sangat bertentangan dengan Undang Undang Nomor 3 Tahun 2009 tentang Mahkamah Agung walaupun putusan tersebut belum mempunyai kekuatan hukum tetap. Mengingat, Undang Undang Nomor 3 Tahun 2009 tentang Mahkamah Agung tersebut tidak menjelaskan terhadap putusan pengadilan pada tingkat apakah yang tidak dapat menangguhkan permohonan peninjauan kembali dan apakah terhadap putusan yang belum mempunyai kekuatan hukum tetap juga berlaku. Sedangkan dalam Pasal 115 Undang-Undang Nomor 51 Tahun 2009 tentang Pengadilan Tata Usaha Negara tentang Peradilan Tata Usaha Negara menyatakan bahwa hanya putusan Pengadilan yang telah memperoleh kekuatan hukum tetap yang dapat dilaksanakan. Hal ini sangat bertolak belakang denga apa yang diamanatkan dari Undang Undang Nomor 3 Tahun 2009 tentang Mahkamah Agung tersebut. sehingga tidak memberikan kepastian hukum aturan mana yang harus dilaksanakan dan ditegakkan.

Berdasarkan uraian di atas maka yang menjadi permasalahan dalam penelitian ini adalah bagaimana eksekusi terhadap pembatalan surat izin mendirikan bangunan pada perkara tata usaha negara.

\section{METODE PENELITIAN}

Penulisan ini menggunakan metode penelitian hukum yuridis normatif (normative research), yaitu penelitian hukum yang dilakukan dengan cara meneliti bahan pustaka atau data skunder (Seokanto dan Sri Muji, 2003, h. 15). Spesifikasi penelitian dalam penulisan ini berupa penelitian deskriptif analistis. Deskriptif adalah menunjukan komparasi atau hubungan seperangkat data dengan seperangkat data yang lain, dan maksudnya adalah untuk memberikan gambaran, menelaah, menjelaskan dan menganalisis (Soekanto, 1996, h. 63).

Sesuai jenis dan sifat penelitiannya, maka sumber data yang digunakan dalam penulisan ini adalah data skunder yang terdiri dari bahan hukum primer berupa peraturan yang terkait dengan eksekusi terhadap pembatalan surat izin mendirikan bangunan pada perkara tata usaha negara. Bahan hukum sekunder terdiri dari buku-buku, jurnal ilmiah, makalah dan artikel ilmiah yang dapat memberi penjelasan tentang bahan hukum primer. Bahan hukum tersier; berupa Kamus Besar Bahasa Indonesia (KBBI) dan lain sebagainya dalam menemukan defenisi dari istilah-istilah dalam membahas hal yang terkait dengan eksekusi terhadap pembatalan surat 
DEIFGA IATA

Jurnal Ilmu Hukum

FAKULTAS HUKUM UMSU
Eksekusi Terhadap Pembatalan...(Zainuddin)

Volume 4 Nomor 2, Juli-Desember 2019, 271-288 DOI: https://doi.org/10.30596/dll.v4i2.3198

izin mendirikan bangunan pada perkara tata usaha negara.

Prosedur yang digunakan untuk mengumpulkan data dalam penilitian ini berupa dokumentasi yaitu pedoman yang digunakan berupa catatan atau kutipan, penelusuran literatur hukum, buku-buku dan lainnya yang bertalian dengan identifikasi masalah dalam penilitian ini dengan cara offline maupun online. Analisa bahan hukum dilakukan dengan menggunakan metode analisa konten (centent analysis method) yang dilakukan dengan menguraikan materi peristiwa hukum atau produk hukum secara rinci guna memudahkan interpretasi dalam pembahasan (Marzuki, 2011, h. 171).

\section{PEMBAHASAN}

\section{Eksekusi Terhadap Pembatalan Surat Izin Mendirikan Bangunan Pada Perkara Tata Usaha Negara}

\section{Tata Usaha Negara}

Istilah hukum tata usaha Negara sejarahnya dijumpai pada Pasal 108 Undang-Undang Dasar Sementara Indonesia Serikat Tahun 1950 yang menyebut "pemutusan tentang sengketa yang mengenai hukum tata usaha diserahkan kepada pengadilan yang mengadili perkara perdata ataupun kepada alat-alat perlengkapan lain, tetapi jika demikian seboleh-bolehnya dengan jaminan yang serupa tentang keadilan dan kebenaran (Suady Husin. 2011, h. 3).

Demikian juga halnya Pasal 142 Undang-Undang Dasar Sementara Republik Indonesia Serikat Tahun 1950 disebutkan bahwa Peraturan-peraturan undang-undang dan ketentuanketentuan tata usaha yang sudah ada pada tanggal 17 Agustus 1950, tetap berlaku dengan tidak berubah sebagai peraturan-peraturan dan ketentuan-ketentuan tata usaha atau kuasa UndangUndang Dasar ini (Suady Husin. 2011, h. 3).

Jadi kedua pasal tersebut Pasal 108 dan 142 Undang-Undang Dasar Sementara Republik Indonesia Serikat Tahun 1950 ni sama dengan Pasal 161 dan 192 Konstitusi RIS yang juga mengunakan istilah Hukum Tata Usaha dan ketentuan-ketentuan tata usaha. Dalam naskah yang ditulis dalam bahasa Belanda (Konstitusi RIS) ternyata untuk sengketa mengenai tata usaha dipakai administratiefrechtelyke geschillen dan ketentuan-ketentuan tata usaha dipakai istilah atau perkataan administrative voorschrriften. Jadi jelaslah bahwa penguasa memakai istilah Hukum Tata Usaha. Hal ini yang ternyata dalam Undang-Undang Nomor 14 Tahun 1970 tentang ketentuan-ketentuan Pokok Kekuasaan Kehakiman Pasal 10 ayat 1 huruf c menyebutkan bahwa kehakiman dilakukan oleh pengadilan dalam lingkungan Peradilan Tata Usaha (Suady Husin. 2011, h. 3-4).

Sehubungan dengan hal di atas tentang Undang-Undang No 14 Tahun 1970 dan amanat Undang-Undang Dasar Negara Republik Indonesia Tahun 1945 maka lahirlah Undang-Undang Nomor 5 Tahun 1986 tentang Peradilan Tata Usaha Negara sebagai payung hukum dalam proses peradilan dibidang administrasi untuk menjamin kesejahteraan warga Negara dalam hal perbuatan yang kesewenangan dilakukan oleh pemerintah yang disebut dengan Pejabat Tata Usaha Negara sebagaimana Pasal 1 ayat 2 Undang-Undang Nomor 5 Tahun 1986 tentang Peradilan Tata Usaha Negara. Dan terakhir undang-undang itu diubah menjadi Undang-Undang 
DEIEGA DATA

Jurnal Ilmu Hukum

FAKULTAS HUKUM UMSU
Eksekusi Terhadap Pembatalan...(Zainuddin)

Volume 4 Nomor 2, Juli-Desember 2019, 271-288

DOI: https://doi.org/10.30596/dll.v4i2.3198

Nomor 51 Tahun 2009 tentang Perubahan kedua atas Undang-Undang Nomor 5 Tahun 1986 tentang Peradilan Tata Usaha Negara.

\section{Pengertian dan Dasar Hukum Tata Usaha Negara}

Pasal 1 angka 7 Undang-Undang Nomor 51 Tahun 2009 tentang Perubahan Kedua atas Undang-Undang Nomor 5 Tahun 1986 tentang Peradilan Tata Usaha Negara memberikan pengertian Tata Usaha Negara adalah administrasi Negara yang melaksanakan fungsi untuk menyelenggarakan urusan pemerintahan baik di pusat maupun di daerah.

\section{Badan atau Pejabat Tata Usaha Negara}

Proses peradilan tata usaha Negara selalu menempatkan badan atau pejabat tata usaha negara selalu sebagai pihak tergugat, sebagaimana ditentukan dalam Pasal 1 angka 12 UndangUndang Nomor 51 Tahun 2009 tentang Pengadilan Tata Usaha Negara yang menyatakan tergugat adalah badan atau pejabat tata usaha negara yang mengeluarkan keputusan berdasarkan wewenang yang ada padanya atau yang dilimpahkan kepadanya, yang digugat oleh orang atau badan hukum perdata.

Menurut ketentuan Pasal 1 angka 8 Undang-Undang Nomor 51 Tahun 2009 tentang Pengadilan Tata Usana Negara yang menyatakan badan atau pejabat tata usaha Negara adalah badan atau pejabat yang melaksanakan urusan pemerintahan berdasarkan Peraturan PerundangUndangan yang berlaku. Di dalam penjelasan disebutkan bahwa yang dimaksud dengan urusan pemerintahan ialah kegiatan yang bersifat eksekutif. Rumusan ini masih ambigu dan tidak jeias (vague), yang di dalam praktek dapat menimbulkan penafsiran yang beragam.

\section{Tugas, Wewenang dan Tanggungjawab Badan atau Pejabat Tata Usaha Negara}

Membicarakan wewenang maka membicarakan bagaimana kedudukan wewenang pemerintahan terhadap penyelenggaraan pemerintahan tidak bisa dilepaskan kaitannya dengan penerapan asas legalitas dalam sebuah konsepsi Negara hukum yang demokratis atau Negara demokrasi yang berdasar atas hukum (Aminuddin Ilmar, 2014, h. 93).

Sesuai konsepsi Negara hukum, wewenang pemerintahan itu berasal dari perturan perundang-undangan yang berlaku. Bahwa organ pemerintahan tidak dapat menganggap ia memiliki sendiri wewenang pemerintahan. Kewenangan hanya diberikan oleh undang-undang. Pembuat undang-undang tidak hanya berikan wewenang pemerintahan kepada organ pemerintahan, akan tetapi juga terhadap para pegawai atau badan khusus untuk itu (Aminuddin Ilmar, 2014, h. 104).

Badan atau Pejabat Tata Usaha Negara (Pejabat TUN) dalam menjalankan tugasnya untuk mengeluarkan suatu Keputusan Tata Usaha Negara harus berdasarkan wewenang masingmasing yang ada padanya atau yang dilimpahkan kepadanya. Sumber dan cara memperoleh wewenang pemerintah bersumber dari undang-undang dasar dan undang-undang. Secara teoritis kewenangan yang bersumber dari peraturan perundangan-undangan tersebut di peroleh melalui 3 (tiga) cara yaitu atribusi (attributie), delegasi (delegatie), dan mandat (mandaat) (Erina Permatasari, 2015). Uriannya adalah sebagai berikut: 
DEIEGA LATA

Jurnal Ilmu Hukum

FAKULTAS HUKUM UMSU
Eksekusi Terhadap Pembatalan...(Zainuddin)

Volume 4 Nomor 2, Juli-Desember 2019, 271-288

DOI: https://doi.org/10.30596/dll.v4i2.3198

a. Atribusi (attributie)

Atribusi adalah pemberian wewenang pemerintahan oleh pembuat undang-undang kepada organ pemerintahan. Berdasarkan Undang-Undang Nomor 30 Tahun 2014 tentang Administrasi Pemerintahan (UU Administrasi Pemerintahan), atribusi adalah pemberian kewenangan kepada badan dan/atau pejabat pemerintahan oleh UndangUndang Dasar Negara Republik Indonesia Tahun 1945 atau undang-undang (Pelimpahan Wewenang Atribusi, Delegasi dan Mandat, 2018).

b. Delegasi (Delegatie)

Delegasi adalah pelimpahan wewenang pemerintahan dari satu organ pemerintahan kepada organ pemerintahan lainnya. Berdasarkan Undang-Undang Administrasi Pemerintahan, delegasi adalah pelimpahan Kewenangan dari Badan dan/atau Pejabat Pemerintahan yang lebih tinggi kepada Badan dan/atau Pejabat Pemerintahan yang lebih rendah dengan tanggung jawab dan tanggung gugat beralih sepenuhnya kepada penerima delegasi (Pelimpahan Wewenang Atribusi, Delegasi dan Mandat, 2018).

c. Mandat (Mandaat)

Mandat terjadi jika organ pemerintahan mengizinkan kewenangannya dijalankan oleh organ lain atas namanya. Berdasarkan Undang-Undang Administrasi Pemerintahan, mandat adalah pelimpahan kewenangan dari Badan dan/atau Pejabat Pemerintahan yang lebih tinggi kepada Badan dan/atau Pejabat Pemerintahan yang lebih rendah dengan tanggung jawab dan tanggung gugat tetap berada pada pemberi mandat (Pelimpahan Wewenang Atribusi, Delegasi dan Mandat, 2018).

\section{Pembatalan Keputusan Tata Usaha Negara (KTUN)}

\section{Pengertian dan Dasar Hukum Keputusan Tata Usaha Negara}

Pengertian Keputusan Tata Usaha Negara menurut Undang-Undang Nomor 5 Tahun 1986 Jo Undang-Undang Nomor 9 Tahun 2004 jo. Undang-Undang Nomor 51 Tahun 2009 adalah sangat penting untuk dipahami, karena dengan memberikan pengertian yang lain tentang apa yang dimaksud dengan Keputusan Tata Usaha Negara, akan mempunyai akibat memberikan pengertian yang salah tentang apa yang dimaksud dengan sengketa Tata Usaha Negara (H. Abdullah Gofar, 2014).

Berdasarkan Pasal 1 angka 9 Undang-Undang Nomor 51 Tahun 2009 tentang Perubahan Kedua Atas Undang-Undang Nomor 5 Tahun 1986 tentang Peradilan Tata Usaha Negara bahwa Keputusan Tata Usaha Negara adalah suatu penetapan tertulis yang dikeluarkan oleh abdan atau pejabat tata usaha Negara yang berisi tindakan hukum tata usaha Negara yang berdasarkan Peraturan Perundang-Undangan yang berlaku, yang bersifat konkret, individual, dan final, yang menimbulkan akibat hukum bagi seseorang atau badan hukum perdata.

H. Abdullah Gofar (2014, h. 24) Apabila diuraikan apa yang dimaksud dengan Keputusan Tata Usaha Negara tersebut, maka ditemukan unsur-unsurnya, sebagai berikut:

1. Penetapan tertulis

2. Dikeluarkan oleh badan atau pejabat tata usaha negara

3. Berisi tindakan hukum tata usaha negara berdasarkan Peraturan Perundang-Undangan

4. Bersifat konkret, individual, dan final

5. Menimbulkan akibat hukum bagi seseorang atau badan hukum perdata. 
Jurnal Ilmu Hukum

FAKULTAS HUKUM UMSU
Eksekusi Terhadap Pembatalan...(Zainuddin)

Volume 4 Nomor 2, Juli-Desember 2019, 271-288

DOI: https://doi.org/10.30596/dll.v4i2.3198

Berdasarkan poin-poin yang diuraikan di atas terkait pengertian Keputusan Tata Usaha Negara maka akan dijelaskan secara satu persatu terkait dari poin-poin tersebut yang menjadi unsure dari pengertian keputusan tata usaha Negara yang dimaksud.

\section{Syarat dan Mekanisme Pembatalan Keputusan Tata Usaha Negara}

Berdasarkan Pasal 53 Undang-Undang Nomor 9 Tahun 2004 tentang Perubahan Atas Undang-Undang Nomor 5 Tahun 1986 tentang Peradilan Tata Usaha Negara menyebutkan bahwa:

(1) Orang atau badan hukum perdata yang merasa kepentingannya dirugikan oleh suatu Keputusan Tata Usaha Negara dapat mengajukan gugatan tertulis kepada pengadilan yang berwenang yang berisi tuntutan agar Keputusan Tata Usaha Negara yang disengketakan itu dinyatakan batal atau tidak sah, dengan atau tanpa disertai tuntutan ganti rugi dan/atau direhabilitasi.

(2) Alasan-alasan yang dapat digunakan dalam gugatan sebagaimana dimaksud pada ayat 1 adalah:

a. Keputusan Tata Usaha Negara yang digugat itu bertentangan dengan Peraturan Perundang-Undanganyang berlaku;

b. Keputusan Tata Usaha Negara yang digugat itu bertentangan dengan asas-asas umum pemerintahan yang baik.

\section{Surat Izin Mendirikan Bangunan}

\section{Pengertian dan Dasar Hukum Surat Izin Mendirikan Bangunan}

Pasal 8 ayat 1 huruf c Undang-Undang Nomor 28 Tahun 2002 tentang Bangunan Gedung menjelaskan "Izin mendirikan bangunan (IMB) adalah surat bukti dari Pemerintah Daerah bahwa pemilik bangunan gedung dapat mendirikan bangunan sesuai fungsi yang telah ditetapkan dan berdasarkan rencana teknis bangunan gedung yang telah disetujui oleh Pemerintah Daerah".

Penjelasan Peraturan Pemerintah Republik Indonesia Nomor 36 Tahun 2005 Tentang Bangunan Gedung menjelaskan bahwa izin mendirikan bangunan gedung yang selanjutnya disingkat IMB adalah perizinan yang diberikan oleh Pemerintah Daerah kepada Pemilik bangunan gedung untuk membangun baru, mengubah, memperluas, dan/atau mengurangi bangunan gedung sesuai dengan persyaratan administratif dan teknis yang berlaku. Izin mendirikan bangunan gedung adalah perizinan yang diberikan oleh Pemerintah Kabupaten/Kota kepada pemilik bangunan gedung untuk membangun baru, mengubah, memperluas, mengurangi, dan/atau merawat bangunan gedung sesuai dengan persyaratan administratif dan persyaratan teknis yang berlaku. Sehingga jelas bahwa IMB itu menjadi penting untuk di miliki sebelum seseorang atau kelompok tertentu dalam membuat gedung (Melalui, http://repository.unpas.ac.id/13413/4/9.\%20BAB\%20II.pdf)

IMB berlaku pula untuk bangunan rumah tinggal lama yaitu bangunan rumah yang keberadaannya secara fisik telah lama berdiri tanpa atau belum ber-IMB. Selain untuk rumah tinggal IMB juga berlaku untuk bangunan-bangunan dengan fungsi yang lain seperti gedung 
Jurnal Ilmu Hukum FAKULTAS HUKUM UMSU
Eksekusi Terhadap Pembatalan...(Zainuddin)

Volume 4 Nomor 2, Juli-Desember 2019, 271-288 DOI: https://doi.org/10.30596/dll.v4i2.3198

perkantoran, gedung industri, dan bangunan fasilitas umum. IMB memiliki dasar hukum yang harus dipatuhi sehingga mutlak harus dimiliki setiap orang yang berniat mendirikan sebuah bangunan. Selain itu, adanya IMB berfungsi supaya pemerintah daerah dapat mengontrol dalam rangka pendataan fisik kota sebagai dasar yang sangat penting bagi perencanaan, pengawasan dan penertiban pembangunan kota yang terarah dan sangat bermanfaat pula bagi pemilik bangunan karena memberikan kepastian hukum atas berdirinya bangunan yang bersangkutan dan akan memudahkan bagi pemilik bangunan untuk suatu keperluan, antara lain dalam hal pemindahan hak bangunan yang dimaksud sehingga jika tidak adanya IMB maka akan dikenakan tindakan penertiban sesuai dengan peraturan yang berlaku (Melalui, http://anggrainidita.blogspot.com/2013/11/v-behaviorurldefaultvmlo.html). Izin mendirikan bangunan adalah perizinan yang diberikan oleh pemerintah kabupaten/kota kepada pemilik gedung untuk membangun baru, mengubah, memperluas, mengurangi dan atau merawat bangunan gedung sesuai dengan persyaratan administrasi dan persyaratan teknis yang berlaku (H. Abdullah Gofar. 2014, h. 24).

\section{Syarat Penerbitan Surat Izin Mendirikan Bangunan}

Peraturan Daerah Kota Medan Nomor. 35 Tahun 2002 Tentang Perubahan Atas Peraturan Daerah Kota Medan Nomor. 4 Tahun 2001 Tentang Pembentukan Organisasi dan Tata Kerja Dinas-Dinas Daerah Di Lingkungan Pemerintah Kota Medan. Peraturan Derah Kota Medan Nomor 9 Tahun Tahun 2002 Tentang Izin Mendirikan Bangunan menyatakan Izin Mendirikan Bangunan memberikan beberapa syarat dalam pengajuan permohonan IMB.

Permohonan IMB ditujukan kepaada walikota Medan c/q Kepala Dinas Tata Kota dan Tata Bangunan dengan mengisi formulir yang telah disediakan dan dengan melengkapi: (Peraturan Derah Kota Medan Nomor 9 Tahun Tahun 2002 Tentang Izin Mendirikan Bangunan)

1. Persyaratan Administrasi:

a. Pengisisan formulir surat permohonan IMB;

b. Foto Copy Kartu Tanda Penduduk yang masih berlaku;

c. Foto Copy SPPT dan pelunasan PBB tahun terakhir;

d. Foto Copy hak atas tanah yang telah dilegalisir oleh pejabat yang berwenang, antara lain:

1) Foto copy sertifikat yang dilegalisir oleh BPN ataupun Notaris;

2) Foto copy akta jual beli dari notaries/camat;

3) Akta yang dikeluarkan oleh notaries dilegalisir oleh notaries;

4) Akta yang dikeluarkan oleh camat dilegalisir oleh camat;

5) Asli surat tidak silang sengketa yang dikeluarkan oleh lurah dan diketahui oleh Camat setempat, bagi surat tanah yang yang bukan seritifikat dan SK Camat;

6) Asli rekomendasi dari Bank bagi tanah yang sedang digunakan;

7) Rekomendasi dari Instansi terkait untuk pembangunan tempoat ibadah, tempat persemayaman mayat, galon (SPBU) dan pendidikan;

8) Asli Surat Kuasa, Akte perusahaan, surat keputusan instans, bagi pemohon yang bukan pemilik tanah (atas nama pemilik tanah). 
2. Persyaratan Teknis:

a. Gambar rencana Bangunan Rangkap 3;

b. Denah/site plan;

c. Tampak (Depan dan Samping);

d. Potongan (Memanjang dan Melintang);

e. Gambar konstruksi (pondasi, sloop,kolom,balok, lantai, tangga, rencana atap/kap, kecuali untuk bangunan rumah tempat tinggal 1 (satu) lantai;

f. Sumur peresapan, septic tank, dan bak control untuk bangunan pagar (Denah, tampak potongan dan situasi);

g. Perhitungan konstruksi yang dibuat oleh konsultan dan ditandatangani oleh perencana, bagi bangunan dengan:

1) Bentangan balok lebih dari enam meter;

2) Ketinggian dua lantai atau lebih bagi bangunan yang digunakan untuk kepentingan umum;

3) Ketinggian bangunan lebih dari tiga lantai;

4) Konstruksi baja atau kayu yang bentangnya lebih dari 12 meter

5) Konstruksi kayu atau baja yang ketinggian tiangnya lebiih dari enam meter perlantai;

6) Perhitungan rencana anggaran biaya (RAB) untuk bangunan tower/menara, Tanki, Gapura/Tugu dan cerebong asap, serta renovasi bangunan.

3. Proses Penerbitan IMB.

\section{Proses dan Mekanisme Penerbitan Surat Izin Mendirikan Bangunan}

Proses penerbitan IMB harus terlebih dahulu memenuhi syarat yang telah dijelaskan sebelumnya, setelah terpenuhinya hal yang demikian itu maka akan dilakukan penandatanganan. Penandatanganan IMB, dengan luas bangunan $<200 \mathrm{~m}^{2}$ ditandatangani oleh Kepala Dinas Tata Kota dan Tata Bangunan Kota Medan, sementara luas bangunan $>200 \mathrm{~m}^{2}$ ditadatangani oleh Walikota Medan. Lama waktu yang dibutuuhkan untuk pengurusan KSB/IMB adalah 16 hari kerja.

Pemohon wajib membayar retribusi ke Kas Pemko Medan melalui Bendaharawan Penerima Dinas Tata Kota Medan dan Tata Bangunan sebelum mengambil IMB yang terbit. Besarnya Retribusi IMB adalah tarif retribusi permeter bangunan X luas bangunan. Pengukuran tanah adalah pengukuran bentuk mdan luas tanah dalam bentuk gambar situasi diberlakukan bagi permohonan izin mendirikan bangunan untuk persil tanah yang belum beralaskan hak sertifikat atau tidak dilengkapi Surat Keterangan Pendaftaran Tanah dan Gambar Situasi Tanah dari Kantor Pertanahan.

\section{Kekuatan Hukum Putusan Atas Pengadilan Tata Usaha Negara yang Berkekuatan Hukum Tetap}

Suatu putusan pengadilan dikatakan mempunyai kekuatan hukum manakala putusan tersebut sudah mempunyai kekuatan hukum tetap atau suatu putusan akhir (eind vonnis) yang terhadapnya tidak diajukan upaya hukum oleh pihak yang merasa keberatan dan/atau putusan kasasi di Mahkamah Agung sebagai lembaga peradilan tertinggi (supreme court) yang bertugas 
Jurnal Ilmu Hukum FAKULTAS HUKUM UMSU
Eksekusi Terhadap Pembatalan...(Zainuddin)

Volume 4 Nomor 2, Juli-Desember 2019, 271-288

DOI: https://doi.org/10.30596/dll.v4i2.3198

untuk mengoreksi/mengevaluasi pertimbangan hukum (judex juris) putusan pengadilan di bawahnya.

Menurut Martiman Prodjohamidjojo, putusan yang telah memperoleh kekuatan mutlak itu mempunyai kekuatan hukum mengikat. Hal yang demikian, lebih dikenal dengan sebutan dalam bahasa latin "resjudicata pro veritate habetur" yang artinya putusan yang pasti dengan sendirinya mempunyai kekuatan mengikat (Martiman Prodjohamidjojo, 2005). Lebih lanjut Martiman Prodjohamidjojo (2005) mengemukakan, suatu putusan pengadilan yang telah mempunyai kekuatan mutlak dapat dijalankan atau putusan tersebut mempunyai kekuatan eksekutorial.

Berkenaan dengan itu, R. Subekti (1977) mengemukakan, tujuan akhir dari proses peradilan adalah untuk memperoleh putusan hakim yang mempunyai kekuatan hukum tetap (in kracht van gewijsde), dalam arti kata suatu putusan hukum yang tidak dapat diubah lagi.

Kekuatan putusan hakim dalam khasanah hukum acara perdata dikemukakan oleh Sudikno Mertokusumo dengan bertolak pada pendapat Asser-Anema-Verdam. Dikatakan, ada 3 (tiga) kekuatan putusan badan peradilan, yakni, kekuatan Mengikat, penyerahan sengketa oleh pihak-pihak kepada pengadilan untuk diperiksa atau diadili, mengandung arti bahwa yang bersangkutan akan tunduk dan patuh pada putusan yang dijatuhkan. Putusan yang telah dijatuhkan itu haruslah dihormati oleh kedua belah pihak. Salah satu pihak tidak boleh bertindak bertentangan dengan putusan (Melalui, http://www.saplaw.top/tag/solusi-penyelesaiansengketa-pertanahan/).

Untuk mendukung kekuatan mengikat suatu putusan pengadilan, terdapat beberapa teori sebagai berikut:

1. Teori hukum materiil, yang mengajarkan bahwa kekuatan mengikat putusan atau "gezag van gewijsde" mempunyai sifat hukum materiil, karena mengadakan perubahan terhadap wewenang dan kewajiban keperdataan, menetapkan, menghapuskan atau mengubah. Putusan itu dapat menimbulkan atau meniadakan hubungan hukum, jadi dapat dikatakan merupakan sumber hukum materiil. Ajaran yang beranggapan bahwa suatu putusan hanya mengikat para pihak dan tidak mengikat pihak ketiga lainnya telah ditinggalkan. Putusan dapat memberi wewenang kepada pihak untuk mempertahankan hak-haknya terhadap pihak ketiga;

2. Teori hukum acara, yang mengajarkan bahwa putusan bukanlah sumber hukum materiil melainkan sumber dari pada wewenang prosesual. Siapa yang dalam suatu putusan diakui sebagai pemilik, ia dengan sarana prosesual dapat bertindak sebagai pemilik terhadap lawannya. Apabila undang-undang mensyaratkan adanya putusan untuk timbulnya keadaan hukum baru, putusan itu mempunyai arti hukum materiil. Ajaran ini dikatakan sangat sempit, sebab suatu putusan bukanlah semata-mata sumber wewenang prosesual, tetapi menuju kepada penetapan yang pasti tentang hubungan hukum yang merupakan pokok sengketa;

3. Teori hukum pembuktian, yang mengajarkan bahwa putusan merupakan bukti tentang apa yang ditetapkan di dalamnya, sehingga mempunyai kekuatan mengikat, karena menurut teori ini pembuktian lawan terhadap isi suatu putusan yang telah memperoleh kekuatan hukum 
Jurnal Ilmu Hukum

FAKULTAS HUKUM UMSU
Eksekusi Terhadap Pembatalan...(Zainuddin)

Volume 4 Nomor 2, Juli-Desember 2019, 271-288

DOI: https://doi.org/10.30596/dll.v4i2.3198

yang pasti tidak diperkenankan. Teori ini termasuk teori kuno yang sudah tidak banyak penganutnya. Mahkamah Agung Republik Indonesia dalam putusannya tanggal 9 November 1955 berpendapat bahwa suatu putusan hakim tidak hanya mempunyai kekuatan terhadap pihak yang kalah, melainkan juga terhadap seorang yang kemudian mendapat hak dari pihak yang kalah tadi;

4. Teori daya ikat, terikatnya para pihak kepada suatu putusan dapat mempunyai arti positif dan dapat pula mempunyai arti negatif. Dalam arti positif, apa yang telah diputus di antara para pihak berlaku sebagai positif benar, "res judicata pro veritate habetur" (apa yang diputus oleh hakim haruslah dianggap benar), dan pembuktian lawan tidak dimungkinkan. Dalam arti negatif, hakim tidak boleh memutus perkara yang pernah diputus sebelumnya antara para pihak yang sama serta mengenai pokok perkara yang sama. Untuk dapat mengajukan tangkisan bahwa suatu putusan mempunyai kekuatan mengikat (exceptie van gewijsde zaak), perkara kedua yang diajukan harus menyangkut hal yang sama dan alasan yang sama;

5. Teori kekuatan hukum yang pasti, yaitu suatu putusan memperoleh kekuatan hukum yang pasti atau tetap (in kracht van gewijsde) apabila tidak ada lagi upaya hukum biasa tersedia. Dengan memperoleh kekuatan hukum yang pasti, putusan itu tidak lagi dapat diubah, sekalipun oleh pengadilan yang lebih tinggi, kecuali dengan upaya hukum luar biasa. Suatu putusan hakim sekalipun terdiri dari motivasi putusan atau pertimbangan hukum dan diktum atau amar, tetapi merupakan kesatuan, sehingga kekuatan mengikat dari pada putusan itu pada umumnya tidak terbatas pada diktum saja, tetapi meliputi juga bagian putusan yang merupakan dasar dari putusan, tetapi tidak meliputi penetapan mengenai peristiwa meskipun telah dikonstatir berdasarkan alat-alat bukti tertentu, dalam perkara terpisah peristiwa tersebut masih dapat disengketakan.

Kekuatan pembuktian, dituangkannya putusan dalam bentuk tertulis, yang merupakan akta otentik, tidak lain bertujuan untuk dapat digunakan sebagai alat bukti bagi para pihak yang mungkin diperlukannya untuk mengajukan banding, kasasi atau pelaksanaannya. Menurut hukum pembuktian dengan putusan telah memperoleh suatu kepastian tentang suatu peristiwa mempunyai kekuatan pembuktian.

Kekuatan eksekutorial, putusan tidak dimaksudkan untuk menetapkan hak atau hukumnya saja, tetapi untuk menyelesaikan sengketa, terutama merealisasikan dengan sukarela atau secara paksa. Oleh karena itu, putusan selain menetapkan dengan tegas hak atau hukumnya juga supaya dapat direalisasi, mempunyai kekuatan eksekutorial, yaitu kekuatan untuk dilaksanakan apa yang ditetapkan dalam putusan itu secara paksa oleh alat perlengkapan negara. Kekuatan eksekutorial diberikan oleh kata-kata "Demi keadilan berdasarkan Ketuhanan Yang Maha Esa". Semua putusan pengadilan di seluruh Indonesia harus diberi kepala irahirah ini, sebagaimana ketentuan Pasal 2 ayat Undang-undang Nomor 48 Tahun 2009 tentang Kekuasaan Kehakiman (Sudikno Mertokusumo, 1993).

Selanjutnya, Indroharto mengemukakan 4 (empat) akibat hukum dari bekerjanya isi dari putusan hakim, yaitu: (R. Subekti, 1977). 
Jurnal Ilmu Hukum

FAKULTAS HUKUM UMSU
Eksekusi Terhadap Pembatalan...(Zainuddin)

Volume 4 Nomor 2, Juli-Desember 2019, 271-288

DOI: https://doi.org/10.30596/dll.v4i2.3198

1. Putusan pengadilan sebagai fakta hukum;

2. Kekuatan putusan pengadilan sebagai akta otentik, yang memiliki kekuatan pembuktian yang sempurna terhadap para pihak dan ahli warisnya, serta bagi mereka yang memperoleh hak dari padanya;

3. Kekuatan menangkis berdasarkan asas ne bis in idem dengan pengertian tidak boleh diajukan perkara lagi dalam hal yang sama. Kekuatan mengikat putusan hakim pengadilan tata usaha negara bagi hakim perdata terlihat dalam situasi:

a) Hakim perdata akan menerapkan asas "ne bis in idem" apabila sengketa yang diputus oleh badan peradilan tata usaha negara diperkarakan kembali pada peradilan umum;

b) Apabila perkara yang pernah diputus pada badan peradilan tata usaha negara, diajukan kembali kepada badan peradilan umum oleh pihak yang belum perkara pada badan peradilan tata usaha negara, putusan badan peradilan tata usaha negara akan dihormati oleh hakim perdata, sebab putusan hakim tata usaha negara berlaku bagi siapapun, sedangkan putusan hakim perdata hanya berlaku bagi pihak-pihak yang bersengketa;

c) Hakim perdata akan memperhatikan yurisprudensi badan peradilan tata usaha negara sesuai dengan perkembangan keadaan.

4) Kekuatan eksekutorial, yaitu kekuatan untuk dapat dipaksakan pelaksanaannya melalui kekuatan umum jika tidak ditaati secara sukarela. Adanya kekuatan ini karena adanya irahirah "Demi keadilan berdasarkan Ketuhanan Yang Maha Esa"

Tidak terdapat pertentangan yang prinsip di antara kedua pedapat tersebut di atas, sehingga dapat disimpulkan sebagai berikut:

a. Kekuatan putusan hakim yang telah dijatuhkan itu mengikat dan haruslah dihormati oleh kedua belah pihak;

b. Putusan berkekuatan sebagai akta otentik dapat dipandang sebagai alat bukti yang sempurna bagi para pihak;

c. Putusan berkekuatan menangkis gugatan berdasarkan asas "ne bis in idem" dengan pengertian tidak boleh diajukan perkara lagi dalam hal yang sama;

d. Putusan berkekuatan merealisasikan dengan sukarela atau secara paksa apa yang telah diputuskan.

Selain itu, Indroharto mengemukakan sifat publik dari putusan hakim tata usaha negara yang menyebabkannya berlaku umum. Inilah perbedaannya dengan putusan peradilan perdata yang hanya mengikat para pihak yang bersengketa (R. Subekti, 1977). Selaras dengan hal tersebut, Sudikno Mertokusumo mengemukakan landasan teoritis yang mendasari kekuatan mengikat putusan hakim. Ia mengatakan, sebagai konsekuensi dari hukum administrasi yang berada dalam lapangan hukum publik, putusan pengadilan tata usaha negara mempunyai daya mengikat secara umum, mengikat bagi siapa saja, prinsip ini dikenal dengan "erga omnes" (Sudikno Mertokusumo, 1983).

Sifat "erga omnes" ini yang membedakannya dengan sifat putusan badan peradilan perdata yang hanya berkekuatan mengikat bagi para pihak yang bersengketa (inter partes) (Sudikno Mertokusumo, 1983). Adanya sarana intervensi dalam Pasal 83 Undang- Undang 
DEIFGA LATA

Jurnal Ilmu Hukum

FAKULTAS HUKUM UMSU
Eksekusi Terhadap Pembatalan...(Zainuddin)

Volume 4 Nomor 2, Juli-Desember 2019, 271-288

DOI: https://doi.org/10.30596/dll.v4i2.3198

Nomor 5 Tahun 1986 tentang Peradilan Tata Usaha Negara dianggap sementara pihak bertentangan dengan sifat "erga omnes" dari putusan badan peradilan tata usaha negara. Jika putusan badan peradilan tata usaha negara mengikat secara umum, tidak ada lagi urgensi pihak lain masuk ke dalam perkara mempertahankan haknya.

Indroharto memperkuat pendapat ini dengan melihat urgensi dan kelayakan pihak lain masuk menjadi pihak dalam perkara. Orang atau badan hukum perdata tidak mungkin menjadi tergugat intervensi, karena yang berkedudukan sebagai tergugat adalah badan/pejabat tata usaha negara, yakni yang melaksanakan urusan pemerintahan (bestuur). Pihak yang berkepentingan dan sependapat dengan tergugat dapat memperkuat dalil tergugat dengan keterangan sebagai saksi, dan tidak perlu menjadi pihak dalam perkara. Demikian juga pihak yang berkepentingan dan sependapat dengan gugatan penggugat dapat memperkuat dalil penggugat dengan keterangan sebagai saksi, dan tidak perlu menjadi pihak dalam perkara (Sudikno Mertokusumo, 1983).

Sehubungan dengan pendapat Indroharto di atas, dengan memberikan tambahan catatan, Irfan Fachruddin menyatakan bahwa ketidakikutsertaan pihak-pihak yang memiliki kepentingan terhadap perkara yang sedang disengketakan harus didukung oleh sifat hukum acara yang sesuai dengan prinsip erga omnes atau keberlakuan umum putusan badan peradilan tata usaha negara (Irfan Fachruddin, 2004, h. 249). Penyelesaian sengketa hendaknya tidak hanya memperhatikan kepentingan pihak-pihak yang bersengketa, tetapi juga dirancang untuk memberikan penyelesaian sengketa dengan memperhatikan kepentingan dan hak-hak yang lebih luas, terutama kepentingan dan hak-hak pihak yang berkepentingan secara langsung dan tidak turut dalam perkara (Irfan Fachruddin, 2004, h. 250).

Lebih lanjut, Irfan Fachruddin mengemukakan, apabila tidak demikian, pihak yang berkepentingan dan tidak menjadi pihak dalam perkara, tidak mempunyai hak untuk melindungi kepentingannya atau melakukan upaya hukum. Pihak yang berkepentingan akan kehilangan kesempatan melindungi kepentingannya jika pihak-pihak menerima putusan dan apabila putusannya hanya bersifat declaratoir yang tidak memerlukan pelaksanaan. Jika putusan bersifat condemnatoir yang masih memerlukan pelaksanaan, masih terbuka kesempatan kepada pihak yang berkepentingan untuk melindungi kepentingannya dengan melakukan perlawanan terhadap pelaksanaan putusan. Agaknya lembaga intervensi masih diperlukan, paling tidak untuk saat ini, guna melindungi pihak yang berkepentingan dari konspirasi pihak-pihak dalam perkara (Irfan Fachruddin, 2004, h. 250).

Berdasarkan uraian di atas, dapat diketahui bahwa, putusan pengadilan tata usaha negara yang berkekuatan hukum tetap (in kracht van gewijsde) bersifat mengikat semua orang (erga omnes) layaknya kekuatan Peraturan Perundang-Undangan, hal ini yang membedakan dari putusan pengadilan umum dalam perkara perdata yang hanya mengikat para pihak yang berperkara (inter partes). Selain itu, putusan pengadilan tata usaha negara yang berkekuatan hukum tetap (in kracht van gewijsde) juga mempunyai kekuatan mengikat yang wajib dipatuhi dan dilaksanakan oleh pihak yang dibebankan kewajiban di dalam putusan yang bersifat condemnatoir. 
DEIEGA LATA

Jurnal Ilmu Hukum

FAKULTAS HUKUM UMSU
Eksekusi Terhadap Pembatalan...(Zainuddin)

Volume 4 Nomor 2, Juli-Desember 2019, 271-288 DOI: https://doi.org/10.30596/dll.v4i2.3198

Putusan pengadilan tata usaha negara yang berkekuatan hukum tetap juga mempunyai kekuatan pembuktian sempurna seperti akta otentik, sehingga dapat dijadikan alat bukti untuk menguatkan bahwa perkara yang diajukan telah pernah diputus sehingga tidak patut untuk diperiksa kembali, yang demikian dikenal dengan asas "ne bis in idem". Lebih dari itu, yang paling penting adalah bahwa, putusan pengadilan tata usaha negara yang berkekuatan hukum tetap (in kracht van gewijsde) mempunyai kekuatan eksekutorial, sehingga siapapun yang dibebankan kewajiban (putusan condemnatoir) harus melaksanakannya, baik secara sukarela maupun dengan upaya paksa.

\section{Akibat Hukum Terhadap Pejabat Tata Usaha Negara yang Tidak Melaksanakan Pembatalan Surat Izin Mendirikan Bangunan}

Ketidakpatuhan tergugat terhadap putusan pengadilan tidak berada di aranah hukum administrasi (publik). Oleh karena itu, bentuk instrumennya bersifat administratif. Walaupun berdasarkan pandangan umum instrument pemaksa itu bersifat lemah atau tidak bertaring, namun dari segi administratif instrument tersebut sudah sangat berat. Jika instrument administratif tidak memadi, masih ada instrument social atau moral dengan mengumpulkan media massa. Instrument social atau moral bagi pejabat sebenarnya dalam masyarakat yang semakin beradab adalah sanksi yang cukup berat (Yuslim, 2015).

Undang-Undang PTUN Perubahan Kedua memberikan penjelasan mengenai akibat hukum yang akan diberikan kepada Pejabat TUN yang tidak melaksanakan Putusan Pengadilan TUN, yaitu pada Pasal 116 ayat 4 menegaskan bahwa "Dalam hal tergugat tidak bersedia melaksanakan putusan pengadilan yang telah memperoleh kekuatan hukum tetap, terhadap pejabat yang bersangkutan dikenakan upaya paksa berupa pembayaran sejumlah uang paksa dan/atau sanksi administratif'. Dan pada Pasal 116 ayat 7 Undang-Undang PTUN Perubahan Kedua menegaskan bahwa "Ketentuan mengenai besaran uang paksa, jenis sanksi administrasi, dan tata cara pelaksanaan pembayaran uang paksa dan/atau sanksi administrasif diatur dengan Peraturan Perundang-Undangan” (Yuslim, 2015).

\section{Ganti Rugi}

Secara teoretis, ganti rugi berasal dari bidang hukum perdata, tentang konsep "onrechtmatige daad". prinsip bahwa setiap tindakan onrechtmatig subjek hukum yang menimbulkan kerugian bagi pihak lain mengharuskan adanya pertanggung jawaban bagi subjek hukum yang bersangkutan merupakan prinsip yang telah diakui dan diterima secara umum. Konsep ini secara yuridis formal di atur dalam Pasal 136, 1365, dan 1367 KUH Perdata. Peraturan Perundang-Undangan yang dimaksud oleh Pasal 116 ayat 7 Undang-Undang PTUN Perubahan Kedua adalah Peraturan Pemerintah Republik Indonesia Nomor 43 Tahun 1991 Tentang Ganti Rugi Dan Tata Cara Pelaksanaannya Pada Peradilan Tata Usaha Negara (Timotheos Enoch Daeli, 2016).

Ganti Rugi yang dimaksud adalah pembayaran sejumlah uang (secara paksa), kepada orang atau badan hukum perdata atas beban Badan Tata Usaha Negara (selanjutnya disebut sebagai Pejabat TUN) berdasarkan putusan Pengadilan Tata Usaha Negara karena adanya 
Jurnal Ilmu Hukum

FAKULTAS HUKUM UMSU
Eksekusi Terhadap Pembatalan...(Zainuddin)

Volume 4 Nomor 2, Juli-Desember 2019, 271-288

DOI: https://doi.org/10.30596/dll.v4i2.3198

kerugian materiil yang diderita oleh penggugat. Besarnya ganti rugi yang dapat diperoleh penggugat paling sedikit Rp.250.000,-(dua ratus lima puluh ribu rupiah), dan paling banyak Rp.5.000.000,-(lima juta rupiah), dengan memperhatikan keadaan yang nyata (Timotheos Enoch Daeli, 2016).

\section{Sanksi Administratif}

Sanksi administrasi ini secara tegas di atur dalam Undang-Undang Aparatur Pemerintah. Sanksi administrasi terbagi dalam tiga (3) golongan yaitu sanksi administrasi ringan berupa; teguran lisan, teguran tertulis, serta penundaan kenaikan pangkat, golongan, dan/atau hak-hak jabatan. Sanksi andministrasi sedang berupa; pembayaran uang paksa dan/atau ganti rugi, pemberhentian sementara dengan memperoleh hak-hak jabatan. Sanksi administrasi berat berupa; pemberhentian tetap dengan memperoleh hak-hak keuangan dan fasilitasnya, pemberhentian tetap, tanpa memperoleh hak-hak keuangan dan fasilitas lainnya serta dipublikasikan di media massa. Setiap sanksi administrasi ini di sesuaikan dengan pelanggaran yang di lakukan oleh pejabat pemerintah (Timotheos Enoch Daeli, 2016).

Selain Undang-Undang Aparatur Pemerintah, sanksi administrasi ini juga di atur dalam Undang-Undang Aparatur Sipil Negara, yang secara khusus mengatur tentang profesi pegawai negeri sipil. Secara eksplisit Undang-Undang Aparatur Sipil Negara ini mengatur tentang kode etik bagi aparatur sipil negara (ASN) untuk melaksanakan ketentuan peraturan perundangundangan. Akan ada sanksi administrasi berupa pemberhentian tidak hormat karena melakukan penyelewengan terhadap Pancasila dan UUD 1945, di hukum penjara atau kurungan karena melakukan tindak pidana kejahatan dan menjadi anggota dan/ atau pengurus partai politik (Timotheos Enoch Daeli, 2016).

Berdasarkan penjelasan sanksi administrasi berdasarkan Undang-Undang Aparatur Pemerintah dan Undang-Undang Aparatur Sipil Negara ini maka apabila Pejabat TUN tidak melaksanakan Putusan Pengadilan TUN yang berkekuatan hukum tetap maka dapat dikenai sanksi administrasi tersebut berdasarkan golongan sanksi yang di atur. Akibat hukum baik ganti rugi dan/atau sanksi administrasi bagi pejabat TUN ini tidak secara serta merta dapat di laksanakan karena ada proses dan tahapan yang harus dilewati. Di samping diumumkan pada media massa cetak setempat sebagaimana dimaksud pada Pasal 116 ayat 5 Undang Undang Nomor 51 Tahun 2009 tentang Pengadilan Tata Usaha Negara, ketua pengadilan harus mengajukan hal ini kepada Presiden sebagai pemegang kekuasaan pemerintah tertinggi untuk memerintahkan pejabat tersebut melaksanakan putusan pengadilan, dan kepada lembaga perwakilan rakyat untuk menjalankan fungsi pengawasan (Timotheos Enoch Daeli, 2016).

\section{KESIMPULAN DAN SARAN Kesimpulan}

Bentuk instrumen terhadap putusan tata usaha negara bersifat administratif, karena ketidakpatuhan tergugat terhadap putusan pengadilan tidak berada di aranah hukum administrasi (publik). Walaupun berdasarkan pandangan umum instrument pemaksa itu bersifat 
lemah atau tidak bertaring, namun dari segi administratif instrument tersebut sudah sangat berat, Undang Undang Nomor 51 Tahun 2009 tentang Pengadilan Tata Usaha Negara pada Perubahan Kedua memberikan penjelasan mengenai akibat hukum yang akan diberikan kepada Pejabat TUN yang tidak melaksanakan Putusan Pengadilan TUN, yaitu pada Pasal 116 ayat 4 Undang Undang Nomor 51 Tahun 2009 tentang Pengadilan Tata Usaha Negara menegaskan bahwa "Dalam hal tergugat tidak bersedia melaksanakan putusan pengadilan yang telah memperoleh kekuatan hukum tetap, terhadap pejabat yang bersangkutan dikenakan upaya paksa berupa pembayaran sejumlah uang paksa dan/atau sanksi administratif”. Dan pada Pasal 116 ayat 7 Undang Undang Nomor 51 Tahun 2009 tentang Pengadilan Tata Usaha Negara menegaskan bahwa "Ketentuan mengenai besaran uang paksa, jenis sanksi administrasi, dan tata cara pelaksanaan pembayaran uang paksa dan/atau sanksi administrasif diatur dengan Peraturan Perundang-Undangan”.

\section{Saran}

Diharapkan dengan adanya instrumen hukum yang mengatur hal yang terkait dengan eksekusi terhadap putusan TUN, semua pihak patuh terhadap hal tersebut, dikarenakan putusan hakim TUN merupakan hukum yang harus di patuhi jika tidak ada lagi upaya hukum. Berkaitan dengan hal tersebut demi menjalankan Asas-Asas Umum Pemerintahan yang Baik, maka Pejabat Tata Usaha Negara ataupun pihak terkait mampu menjalankan perintah UndangUndang. 
Jurnal Ilmu Hukum

FAKULTAS HUKUM UMSU
Eksekusi Terhadap Pembatalan...(Zainuddin)

Volume 4 Nomor 2, Juli-Desember 2019, 271-288 DOI: https://doi.org/10.30596/dll.v4i2.3198

\section{DAFTAR PUSTAKA}

Daeli, Timotheos Enoch. (2016). Skripsi Akibat Hukum Tidak Dilaksanakan Putusan Pengadilan Tata Usaha Negara Salatiga.(Skripsi Program Sarjana Ilmu Hukum Fakultas Hukum Universitas Kristen Satya Wacana).

Dahlan, Ahmad, dkk. (2013). Faktor Penyebab Tidak Dilaksanakannya Putusan Pengadilan Tata Usaha Negara Dan Upaya Penanggulangannya (Analisis Kasus Putusan Ptun Medan No: 17/G/2000/Ptun-Mdn). Jurnal Mercatoria Vol. 6 No. 2/Desember 2013.

Erliyana, Anna. (2005). Keputusan Administrasi Negara (Beschikking). Low Review. Fakultas Hukum Universitas Pelita Harapan, Vol. IV. No. 3 Marei 2005.

Gofar. H. Abdullah. (2014). Teori dan Praktek Hukum Acara Peradilan Tata Usaha Negara. Malang: Tunggal Mandiri.

Hukum Online. (2018). Paulus E. Lotulung: Hakim PTUN Tak Usah Takut Kehilangan Perkara. Diakses pada tanggal 18 Agustus 2018 melalui www. Hukumonline.com

Husin, Suady. (2011). Hukum Tata Pemerintahan Suatu Pengantar. Laboratorium Pendidikan Pancasila FIS Unimed.

Ijin Mendirikan Bangunan. (2017). Diakses pada tanggal 5 Desember 2017 melalui http: www.wikipedia.com.

Ilmar, Aminuddin. (2014). Hukum Tata Pemerintahan. Jakarta: Prenadamedia Group.

M, Ali Abdullah. (2015). Teori dan Praktek Hukum Acara Peradilan Tata Usaha Negara Pasca-Amandemen. Jakarta: Prenadamedia Group.

MA Batalkan IMB Podomoro Deli City Medan, Gini Sikap Pemko Medan. (2018). Diakses pada tanggal 28 Mei 2018 melalui www.medan.tribunnews.com

Mas, Marwan. (2004). Pengantar Ilmu Hukum. Makassar: Ghalia Indoneia.

Metodologi Penelitian. (2018). Diakses pada tanggal 10 September 2018 melalui www.akupunktursolo.files.wordpress.com

Minta Podomoro Dirobohkan, Yayasan Citra Keadilan Kirim Somasi Ke Walikota Medan. (2018). Diakses pada tanggal 1 September 2018 melalui www.rmolsumut.com

Pelimpahan Wewenang Atribusi, Delegasi dan Mandat. (2018). Diakses pada tanggal 10 September 2018 melalui $\quad$ www.palangkaraya.bpk.go.id

Pengertian Data Primer dan Data Sekunder (2018). Diakses pada tanggal 10 September 2018 melalui melalui www.kanalinfo.web.id

Peraturan Pemerintah Nomor 36 Tahun 2005 tentang Bangunan Gedung.

Permatasari, Erina. (2015). Konsep Sumber Kewenangan Pejabat Tata Usaha

Sebagai Dasar Pembatalan Keputusan Tata Usaha Negara (KTUN).

Negara

Program Sarjana, Program Sarjana Ilmu Hukum Fakultas Hukum Universitas Jenderal Soedirman, Purwokerto).

Rani, Uwaisyah. (2014). Urgensi Upaya Paksa Dalam Pelaksanaan Putusan Pengadilan Tata Usaha Negara. Jurnal JOM Fakultas Hukum Volume I Nomor 2 Oktober 2014.

Soekanto, Soerjono. (1986). Pengantar Penelitian Hukum. Jakarta: Universitas Indonesia (UI-press). 
Sunggono, Bambang. (2015). Metodologi Penelitian Hukum. Jakarta: Rajawali Pers.

Tim Penyusun. (2014). Pedoman Penulisan Skripsi. Medan: Fakultas Hukum Univeristas Muhammadiyah Sumatera Utara.

Undang Undang Nomor 28 Tahun 2002 tentang Bangunan Gedung.

Undang Undang Nomor 3 Tahun 2009 tentang Perbuhan kedua atas Undang Undang Nomor 14 Tahun 1985 tentang Mahkamah Agung.

Undang Undang Nomor 51 Tahun 2009 tentang Perubahan Kedua Atas Undang Undang Nomor 5 Tahun 1986 tentang Peradilan Tata Usaha Negara.

Walisongo, Eprintis. (2018). Metode Penelitian. Diakses pada tanggal 10 September 2018 melalui www.eprintis.walisongo.ac.id.

Wantu, Fence. M.. (2014). Hukum Acara Peradilan Tata Usaha Negara. Gorontalo: Reviva Cendekia.

Yuslim. (2015). Hukum Acara Peradilan Tata Usaha Negara. Jakarta: Sinar Grafika.

Yusrizal. (2015). Modul Hukum Acara Peradilan Tata Usaha Negara. Lhokseumawe: Unimal Press. 